\title{
ANALYSIS OF THE ROLE OF BPK IN PREVENTING AND ERADICATING CORRUPTION (A STUDY IN 4 DISTRICTS IN SOUTH SULAWESI PROVINCE)
}

\author{
Junaidi \\ STIE Muhammadiyah Palopo \\ Email : junaidij45@yahoo.co.id
}

\author{
Article history: \\ Received July 31, 2015 \\ Revised December 22, 2015 \\ Accepted May 12, 2016

\section{JEL Classifications} \\ H59

\section{Key Words:} \\ Financial transactions, \\ fraud, \\ pressure, \\ opportunity, \\ rationalization.
}

ARTICLE INFORMATION

\section{DOI:}

10.21532/apfj.001.16.01.02.18

\begin{abstract}
The objective of this study is to test the ability of BPK (the Audit Board of the Republic of Indonesia) in preventing and eradicating corruption in regional government (district). In this study, the examination is focused on the factors that affect the treasurers to commit fraud, especially in the financial management and financial transaction area, based on the fraud triangle theory. This study is based on the interviews with 87 treasurers and former treasures period 2008-2012. The result of this study indicates that pressure and rationalization have a positive relationship with fraud. The result provides partial support for the fraud triangle theory in explaining the phenomenon of fraud. The role of BPK is as a strategic government auditor in preventing and combating corruption in regional government.
\end{abstract}

\section{INTRODUCTION}

Regional Government Financial reform is characterized by the enactment of Law No. 22 of 1999 on Regional Government and Law No. 25 of 1999 on Financial Balance between Central Government and Regional Government replacing Law No. 5 of 1974 on the principles of Regional Government and Law No. 32 of 1956 on the Financial Balance between Central Government and Regional Government in managing their own household. The reform occurred after the era of regional autonomy and the demands for professionalism of the government officials in managing the existing budget for the realization of regional government policies and goals set forth in the regional budget (APBD). 
Up to this moment the disclosures of alleged corruption cases in various regions with the number of suspects / accused / convict involving the legislative and the executive continue to grow. And these have been going on since 2002. Previous corruption reports had been dominated by the corruption in legislative, but recently there was increased tendency of corruption committed by the executive. According to the Director General of Regional Autonomy of the Ministry of Home Affairs, Djohermansyah Djohan, until January 2014 there had been as many as 318 people of a total of 524 Regional Heads and Deputy Regional Heads stuck with cases of corruption. This occurred since the implementation of direct elections. Based on data from ICW (Indonesian Corruption Watch), in 2014 approximately 43 Regional Heads became the suspects, and of course, these numbers continued to grow in 2015.

It could be said that the phenomenon of the disclosure of so many corruption cases at the regional level has never happened in the history of Indonesia. Why? Some people assume that decentralization of policy has fostered corruption at the regional level. Rampant corruption cases have occurred shortly after the implementation of the policy of regional autonomy or decentralization of government. With the enactment of Law No.22 of 1999 on Regional Government, the regional government agencies have more power, especially in the budget management which has implications for the increased opportunities for corruption in the regional level.
As a government auditor, according to Law No. 15 of 2004 Article 16 (1) BPK is obliged to provide opinions, as professional statements of auditor, on the fairness of financial information presented in the financial statements. Criteria for the provision of opinions are: (a) conformity to the government accounting standards, (b) adequate disclosures, (c) compliance with laws and regulations, and the effectiveness of the internal control system. Based on the audit results of BPK (the Audit Board of the Republic of Indonesia), the biggest potential abuse of the regional financial management is in the weak internal control and noncompliance with laws and regulations.

\section{Internal Control System}

The audit results of the First Semester of 2014 showed 5,948 cases of weakness of internal control system consisting of 3 (three) finding groups, namely: the weakness of accounting and reporting control system, the weaknesses of budget implementation control system, and the weakness of the internal control structure as presented in table 1.

\section{Tabel 1 : Finding Group of Internal Control System Based on the Audit Result}

\begin{tabular}{|c|l|c|}
\hline No. & \multicolumn{1}{|c|}{ Finding Groups } & $\begin{array}{c}\text { Number } \\
\text { of Cases }\end{array}$ \\
\hline 1 & $\begin{array}{l}\text { The Weakness of Accounting } \\
\text { and Reporting Control System }\end{array}$ & 2,136 \\
\hline 2 & $\begin{array}{l}\text { The Weakness of Budget } \\
\text { Implementation Control } \\
\text { System }\end{array}$ & 2,498 \\
\hline 3 & $\begin{array}{l}\text { The Weakness of Internal } \\
\text { Control Structure }\end{array}$ & 1,314 \\
\hline & \multicolumn{2}{|c|}{ Total } \\
\hline
\end{tabular}


Based on the audit results of BPK (the Audit Board of the Republic of Indonesia), the weakness of regional government financial management is in the weakness of internal control and noncompliance with laws and regulations. As in Table 1, the dominant weakness of internal control system is the weakness of the budget implementation control system as many as 2,498 cases or $42 \%$ of total weaknesses of internal control system. These findings increased compared to the previous periods.

\section{Compliance with Laws and Regulations}

Non-compliance with Laws and Regulations results in losses to the state/region, potential loss of state / region, lack of revenue, administrative weakness, inefficiency, and ineffectiveness. The audit results of the First Semester of 2014 showed 7,173 cases of non-compliance with laws and regulations with the potential losses to the state / region of IDR 10,928,527.26 million, of which there were indications of loss of state / region, as many as 418 cases, amounting to IDR 400,659.93 million. The number and value of each are presented in Table 2 and the percentage of findings of non-compliance with existing legislation is in Graph 2.

Tabel 2 : The Finding Group of Non-Compliance with Laws and Regulations Based on the Audit Result

(Value in IDR Million)

\begin{tabular}{|c|c|c|c|}
\hline No. & Finding Groups & Number of Cases & Value \\
\hline \multicolumn{4}{|c|}{ Non-Compliance with Laws and Regulations resulting in } \\
\hline 1 & State/Regional Losses & 2,790 & $1,464,508.48$ \\
\hline 2 & Potential State/Regional Losses & 431 & $4,668,797.17$ \\
\hline \multirow[t]{2}{*}{3} & Lack of Revenue & 1,120 & $1,452,944.63$ \\
\hline & Sub-Total 1 & 4,341 & $7,586,250.28$ \\
\hline 4 & Administration & 2,512 & \\
\hline 5 & Inefficiency & 155 & $69,250,71$ \\
\hline \multirow[t]{3}{*}{6} & Ineffectiveness & 165 & $3,273,026.27$ \\
\hline & Sub-Total 2 & 2,832 & $3,342,276.98$ \\
\hline & Total & 7,173 & $10,928,527,26$ \\
\hline
\end{tabular}




\section{Graph 1}

Percentage of Finding on Non-Compliance with Laws and Regulations based on the Audit

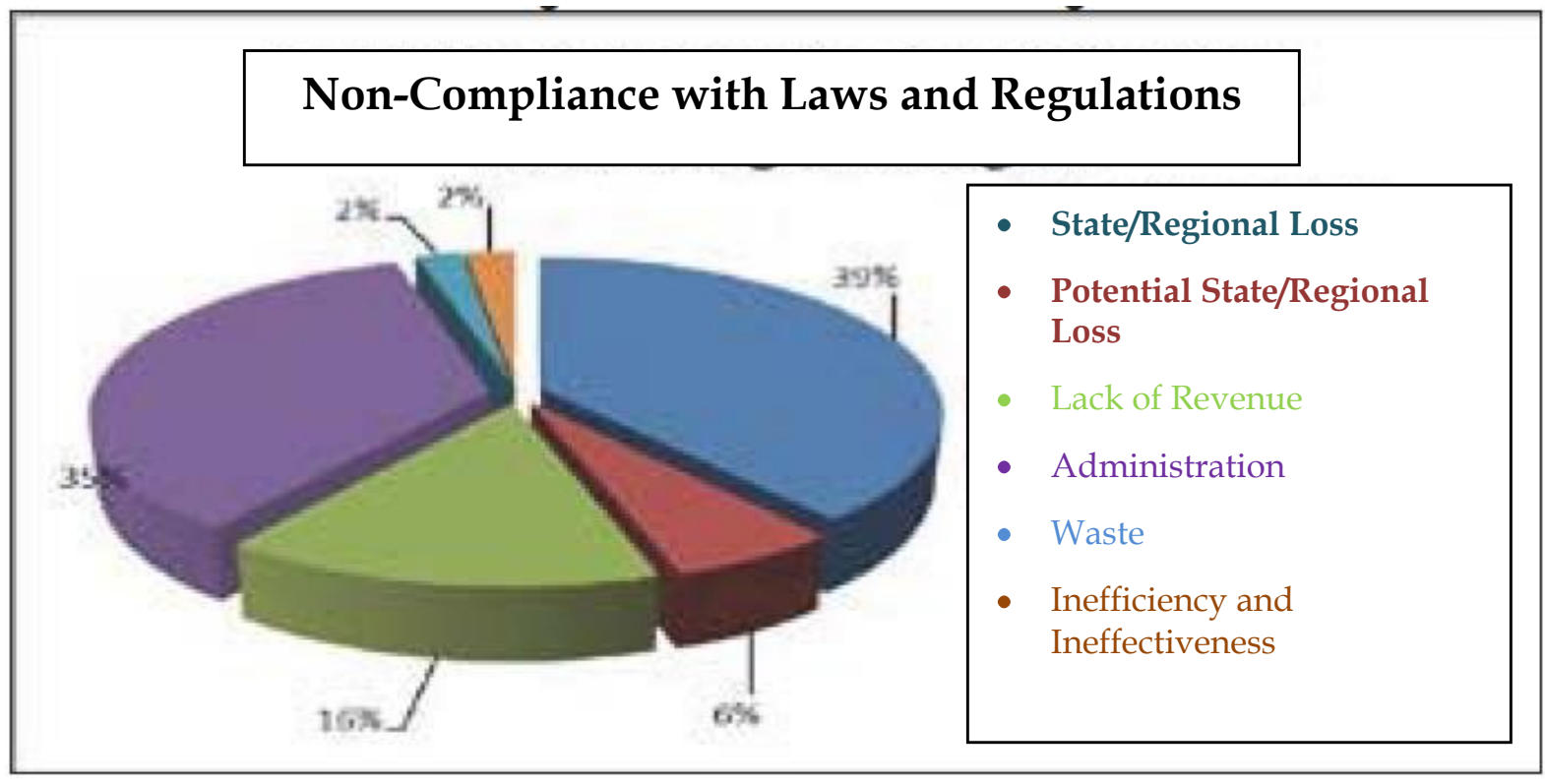

Based on the regulation of BPK No. 01 of 2007 on state financial audit standards, noncompliance is different from fraud or deviation from the provisions of the legislation. The occurrence of non-compliance is not caused by fraud or deviation from the provisions of legislation. But in this case, non-compliance is an unreasonable action or beyond the usual practices.

\section{Fraud, Waste dan Abuse}

According to Singleton (2002), the definition of fraud can vary depending on who defines it and how the condition of the person who defines it. One can define fraud as intentional fraud (including lying and cheating), and is the opposite of the truth, justice and honesty. Fraud has many definitions, among others are as follows:

a. Fraud is a criminal act that describes any dishonest act (cheating) to gain. b. Corporate Fraud is the fraud which is committed by, for and against a business corporation

c. Management Fraud is a deliberate misstatement by companies committed by employees within the company's management with the aim of promotions, bonuses or other economic benefits, as well as status symbol.

d. Fraud, according to general public, is dishonesty in the form of deliberate fraud or intentional misstatement of a material fact.

\section{According to GAO (Government} Accountability Office) in Tuanakotta (2013, p: 30-31), waste is expenditure, consumption, mismanagement or potentially detrimental to the government. Waste includes unnecessary costs for practices, inefficient or ineffective system or control. Waste typically does not end on the accusations or charges of fraud. However, 
the accusations or charges could happen. Waste will turn into fraud, if the elements of intent are found.

Abuse, according to GAO, is destruction, misapplication, excessive use, or abusive or destructive deed. The abuse of authority is done by way of:

1. Excessive or improper use of resources or the use of resources in a way that is contrary to the natural ways or statutory provisions;

2. Intentional destruction, diversion, manipulation, misapplication, maltreatment on the resources owned or managed by the government; or

3. Extravagant or excessive use which gives rise to the abuse of position or authority;

4. Abuse does not necessarily lead to the accusations or charges for the occurrence of fraud. However, the accusations or charges could happen.

\section{Fraud Triangle}

Cressey (1953) states that fraud is caused by three factors: pressure, opportunity, and rationalization which are often called the fraud triangle. This theory has been adopted in auditing standards and is considered as one of the primary literature in explaining the phenomenon of fraudulent financial statements. Nevertheless, the ability of the theory to explain the phenomenon of fraudulent financial statements has not been empirically proven.

Pressure is the pressure perceived by the perpetrator which is seen as financial needs that cannot be told to others. Opportunity is a chance to commit fraud as perceived by the perpetrators of fraud. Rationalization is a whisper to fight against the conscience of the perpetrators of fraud. Skousen et.al. (2009) and Dorminey et.al (2012) empirically examines the ability of fraud triangle theory in explaining the fraud.

\section{Previous Researches}

Alesina and Drazen (1991); Tavares (2004) and Mierau et al. (2007) found that the number of political parties can reduce the level of corruption, and when economic access is heavier that political access, people will enter the political arena to earn money and this can lead to the increased political corruption and economic corruption. The less developed the political parties, the broader level of corruption because of weak supervision.. (Shleifer and Vishny, 1993; Sandholtz and Koetzle, 2000; Treisman, 2000; Agatiello 2010; Graycar and Sidebottom, 2012; Jetter, et. Al, 2015).

Dreher, Kostogiannis and McCorriston (2004) identified four factors as the causes of corruption, namely political and judicial factor, historical factor, social and cultural factor, and economic factor. Social and cultural factor is intrinsically related to moral behavior. People who have commendable moral qualities tend to abstain from acts of corruption. In making decision and implementing programs in a variety of activities, they tend to shy away from the actions that could harm others or other parties and vice versa.

According to La Porta (1999), Treisman (2000) and Alesina (2003), social and cultural factors play a special role in identifying the 
level of corruption in a country. Religion and social system have an influence in suppressing corruption. Economic factor, such as economic openness (Dreher, 2006; Treisman, 2000), public sector in the economy (Tanzi, 1998; Treisman, 2000), and the level of remuneration in public sector (Rijckeghem and Weder, 1997) have a direct impact on the level of corruption in a country. Furthermore, Aguilera and Vadera (2008) distinguished typology of corruption based on the complexity and corruption practice around the world.

Henderson and Kuncoro (2012), who examined the flow of political parties in Indonesia, said that political parties are dominant factors affecting the level of corruption in a period and a region in Indonesia. Modus of fraud and corruption are committed by bribing the politicians and law enforcers as well as the bureaucrats in getting services.

\section{Corruption in Indonesia}

Arifianto (2004) stated that there are three theories that could explain the occurrence of corruption in Indonesia, namely mainstream economic theory, patrimonialism theory, and kleptocratic state theory. The first theory explains that the state often acts monopoly on the country's economic activity. The second theory argues that corruption can act as a way to increase political integration among the peoples, parties and factions in the government. The third theory suggests that corruption is endemic in the regime controlled by the leaders of the country that have the purpose, by their positions, only to enrich themselves.
Harold D. Laswell, in the book "Who Gets What, When, How", said: "Politics is the issue of who gets what, when, and how. Based on this opinion, the way a person gets a public authority is done with certain ways, for example, when a person obtains a public office using money politics way, in running his power he has the potential to commit acts that violate the law, such as corruption. Corruption is an unlawful act because it misappropriates public authority for certain interests.

\section{Data Sources}

In this study, interviews were conducted with 87 treasurers and former treasurers in four Districts in South Sulawesi Province in 20082012. The topics of discussion were about the factors that encourage the treasurers of expenditure, as the most responsible party, if BPK finds elements of fraud, waste and abuse in their financial management. Furthermore, the results of these interviews were confirmed to the Inspectorate and BPK.

\section{DISCUSSION}

\section{Graph 2:}

Factors that influence the treasurer of expenditure to commit fraud

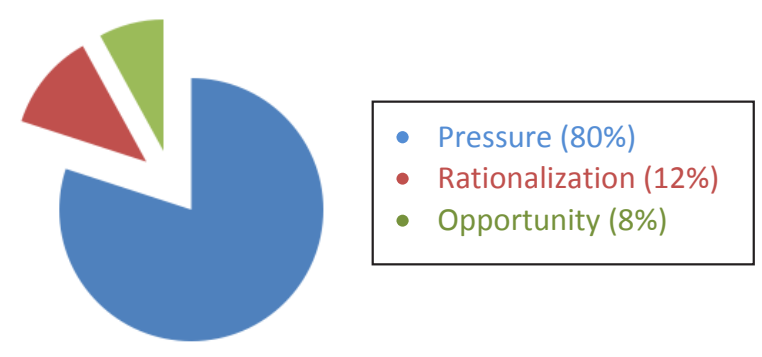


Based on the interview, in running the duties, $80 \%$ of them feel burdened by the intervention of their direct supervisor and external parties such as family parties. This intervention may include a policy that violates the rules, such as the intervention to make payments to third parties that are not in the budget activities or the payments that exceed budget limit. Due to such violation, the treasurers of expenditure then make the accountability reports that do not meet formal and judicial conditions on other activities. $12 \%$ of indications of fraud action, based on rationality, show that some of the treasures do the same thing, while the remaining, the factor of opportunity, shows that not all budgets are used up.

The implications of this intervention are: realizing expenditure which is not supported by evidence of liability in accordance with provisions, marking up the budget, and creating fictitious activities and accountability report. Most budget items which are widely manipulated by the treasurers include official travel expenditures, grants, and social assistance. These fraudulent activities in accountability report certainly become the finding of BPK, either in administration, waste, or potential harm in the state/regional finances (indications of corruption).

The question is "How do the treasurers of expenditure address the findings of BPK? If the finding is only in administrative activities, such as the obligation to immediately pay / deposit the regional loss to the regional treasury, the treasurers generally use the remaining funds without accountability and use the reserve money because BPK usually makes an audit three (3) months after the fiscal year ends. As a result, the treasurers of expenditure manipulate the accountability report and increase the regular budget such as manipulation of the official travel evidence, irregularities of submission procedures, and disbursement of funds as well as the manipulation of the rest of the Regional Budget.

According to the rules of law, Parliament is the party that has a major role in following up the findings of BPK, because Parliament has monitoring function in the implementation of the Regional Budget. Being tied up by economic and political interests makes the role of Parliament less optimal because the regional head sometimes also serves as the chairman of political party that holds a majority of parliament seats. According to Rinaldi, Purnomo and Damayanti (2007), in some regions, the Parliament's role in dismantling corruption is strong. It is due to political interests, in which the regional head is on the opposing party. In some places, one of the perpetrators of fraud also involves some members of Parliament.

Where is the Inspectorate? As long as the Inspectorate is still under the auspices of the regional head, the Inspectorate could not be expected to do a good job. Although this SKPD (Regional Work Unit) serves to conduct inquiries and investigations into alleged irregularities or abuse of authority, either through its own findings or through complaints or information from various parties, in carrying out its duties and functions SKPD is responsible to the regional head through 
the Regional Secretary. Neither of the cases is revealed as a result of the report of Inspectorate (Inspectorate), a supervisory institution under the control of the regional head.

\section{CONCLUSION AND SUGGESTION Conclusion}

Compared with other law enforcement agencies such as the Attorney, the National Police and Anti-Corruption Commission (KPK), in preventing corruption, BPK has a very strategic role to carry out performance checks and specific goals that can support the disclosure of fraud, including corruption. BPK's audit report could be valid records and supporting data to know the initial indications of corruption as well as preventive measures.

As the government's external auditor, BPK should ideally not be too preoccupied by the audit monopoly, particularly on the compliance with the budget governance that seems never be completed. As a result, chronic and recurring governance error can never be fixed and even seem to be allowed, for example, in grant, social assistance and improvement of public services, such as licensing and payment of regional taxes.

One of the factors that have caused the proliferation of corruption over the years is the discretionary authority of BPK not to submit the findings of potential losses to the law enforcers when they have been returned. In fact, the BPK's audit findings are much more qualified than public complaints in general. Audit findings on the result of fraud detection will facilitate the determination of the suspect. BPK can find risk factors that correlate with certain characteristics of the same examination object (corruption with variables existing in regional government).

\section{Suggestion}

The number of BPK members should not be too many much less the partisans who have no background in auditing. It is believed to have strong correlation with the quality of audit report. The argument is that BPK is a professional audit institution whose output is not a political product. The independence of BPK in recruiting personnel is strongly needed, because so far BPK has been dependent on the government as well as promotion policy. There is an impression that the independence of BPK is just a discourse. Political interest has been successfully reducing the performance of BPK. In the field of prevention, President, Ministry of Home Affairs and Ministry of Finance need to conduct monitoring closely so that the BPK's recommendation for governance improvement could be obeyed. Laws even provide criminal sanctions when the BPK's recommendation is ignored.

\section{REFERENCES}

Agatiello, O,R, 2010, Corruption not an end Geneva School of Diplomacy and International Relations, Geneva, Switzerland, Management Decision Vol. 48 No. 10; pp. 1456-1468

Alesina, A., Drazen, A., 1991, Why are stabilisations delayed ? The American Economic Review 81 (5), 1170-1188.

Arifianto, Alexander, 2004, Corruption In Indonesia: Causes, History, Impacts, And Possible Cures.

Cressey, D.R, 1950, "Criminal violation of fiancial trust", $\mathrm{PhD}$ Thesis, IN University, Department of Sociology.

Dreher, et. al, 2004, Coruption around the world : evidence from a struktural model 
Dorminey, et.al, 2012, "The evolution of fraud theory", Issues in Accounting Education, Vol. 27 No. 2, pp. 555-579.

Graycar,Adan Sidebottom,A;2012,"Corruption and control: a corruption reduction approach", Journal of Financial Crime, Vol. 19 Iss 4 pp. 384-399

Henderson, J.V dan Kuncoro, A, 2011, Corruption and local democratization in Indonesia: The role of Islamic parties, Journal of Development Economics 94 , p. $164-180$

Kristiansen, S. and Ramli, M. 2006, "Buying an Income: the market for civil service positions in Indonesia", Contemporary Southeast Asia, Vol. 28 pp. 207-233.

Jetter, M, Agudelo A.M, dan Hasan, A.R, 2015, The Effect of Democracy on Corruption: Income is Key; World Development Vol. 74, pp. 286-304

Kuncoro, A, 2006, "Corruption and business uncertainty in Indonesia", ASEAN Economic Bulletin, Vol. 23 No. 1, pp. 1130.

Laswell, H.D, 1959, Who Gets What, When, How, New York: Meridian Books, Inc

Mierau, J., Jong-A-Pin, R., de Haan, J., 2007. Do political variables affect fiscal policy adjustment decisions? New empirical evidence. Public Choice 133 (3), 297319.

Republik Indonesia, Undang-undang nomor 15 Tahun 2004 tentang Badan Pemeriksa Keuangan
Rijckeghem, R.V dan Weder, B, 1997, 'Corruption and the Rate of Temptation: Do Low Wages in the Civil Service Cause Corruption?' (Washington, D.C.: IMF Working Paper No. 97/93

Rose-Ackerman, Susan. 1999. Corruption and Government: Causes, Consequences, and Reform. Cambridge, England: Cambridge University Press.

Singleton. T dan Singleton. A, 2002, Fraud Examination.Thomson Learning. USA

Sandholtz, W dan Koetzle. W, 2000, 'Accounting for Corruption: Economic Structure, Democracy, and Trade', International Studies Quarterly, 31-50.

Shleifer, Adan Vishny, R.W, 1993, 'Corruption', Quarterly Journal of Economics, 108, 599-617.

Tanzi, V., Davoodi, H., 1997, Corruption, public investment, and growth. IMF Working Paper WP/97/139.

Tanzi, V., 1998, Corruption around the world: causes, scope and cures. IMF Staff Papers 45, 559-594.

Tavares, J., 2004, Does right or left matter? Cabinets, credibility and fiscal adjustments, Journal of Public Economics 88 (12), 2447-2468.

Tuanakotta, T.M, 2013, Mendeteksi manipulasi laporan keuangan, Jakarta : Salemba Empat

www.beritasatu.com/hukum/249903-icw43-kepala-daerah-tersangka korupsidominan-berafiliasi-ke-partai-tertentu. html; diakses pada 21 Juli 2015 
Fajar Laksono Soeroso : Political Corruption Prevention In Regional.....

Page 215-226 